\title{
E-Tailing Consumer Adoption in The Indonesian Fashion Industry: The Role of Technology Acceptance Model
}

\author{
Aldi Ramdhani Fahlevi Deisti ${ }^{1 *}$, Ira Siti Sarah ${ }^{1}$, Ivon Sandya Sari Putri ${ }^{1}$ and \\ Leni Nur Pratiwi ${ }^{2}$
}

${ }^{1}$ Department of Business Administration, Politeknik Negeri Bandung, Indonesia

${ }^{2}$ Department of Accounting, Politeknik Negeri Bandung, Indonesia

\begin{abstract}
:
The retail web system, also known as e-tailing, has utilized by many national and multinational fashion companies in Indonesia. However, many consumers are hesitated to adopt this new kind of transaction channel. This study aims to test consumers' adoption of e-tailing in the Indonesian fashion industry using technology acceptance model (TAM), i.e. perceived ease of use (PEU), perceived usefulness (PU), and attitude towards using (ATU). A quantitative approach was used in this study. The web user of 169 respondents was asked to fill in a questionnaire. The collected data was then analysed using structural equation modelling (SEM). The result finds e-tailing adoption is strongly impacted by perceived ease of use, perceived usefulness, and attitude towards using. This study suggests sales manager hear consumers' needs and behaviour when they go shopping online.
\end{abstract}

Keywords: attitude towards using, consumers' adoption, e-tailing, perceived ease of use, perceived usefulness, technology acceptance model

\begin{abstract}
Abstrak:
Sistem laman ritel, atau yang dikenal pula sebagai e-tailing, telah digunakan oleh banyak perusahaan mode nasional dan multinasional di Indonesia. Namun, banyak konsumen yang ragu untuk mengadopsi model transaksi baru ini. Penelitian ini bertujuan untuk menguji adopsi konsumen e-tailing di industri mode Indonesia menggunakan model penerimaan teknologi (TAM), yaitu persepsi kemudahan penggunaan (PEU), persepsi kegunaan (PU), dan sikap terhadap penggunaan (ATU). Penelitian ini menggunakan pendekatan kuantitatif. Pengguna laman dari 169 responden diminta untuk mengisi kuesioner. Data yang terkumpul kemudian dianalisis dengan menggunakan pemodelan persamaan struktural (SEM). Hasilnya menunjukkan bahwa adopsi $e$-tailing sangat dipengaruhi oleh persepsi kemudahan penggunaan, persepsi manfaat, dan sikap terhadap penggunaan. Penelitian ini menyarankan agar manajer penjualan mendengar kebutuhan dan perilaku konsumen ketika mereka berbelanja online.
\end{abstract}

Kata Kunci: sikap terhadap penggunaan, adopsi konsumen, e-tailing, persepsi kemudahan penggunaan, persepsi manfaat, model penerimaan teknologi 


\section{Introduction}

Information technology is growing very fast. The development of information technology is supported by the appearance of the Internet, networks of computer which interconnected, every network connects tens, hundreds, to thousands of computers, which makes it possible for computers to share valuable data and pieces of information (Nugroho, 2006). In Indonesia, the entry of the Internet was started around 1994. According to the latest data from (Indonesia Internet Service Provider Association, 2018), internet usage in Indonesia have reached more than 139 million users compared to 2 million users in 2000.

This rapid development of the Internet exposed a high benefit to retail business. Business transactions that formerly made in the brick and mortar store, is shifted to a more-convenient smartphone or personal computer. A practice that is well known as e-commerce, or online buying and selling of physical goods (Nugroho, 2006). E-commerce in Indonesia is defined as social commerce and e-tailing. Social commerce involves online transactions through social media platform in which goods listed for sale on the seller-made private account, but payment and delivery are handled elsewhere. Meanwhile, e-tailing means the online transaction is conducted an online platform that facilitates all needs of retail business from product display to product delivery. Although social commerce shows a high popularity in the teenage market, e-tailing still dominate Indonesian online market comprising about US\$5 billion (Das, Tamhane, Vatterott, Wibowo \& Wintels, 2018).

With the increasing recognition of e-tailing for business success, e-tailing is considered a promising channel for retail company to broaden its market. However, factors contributing to consumers' adoption on e-tailing are still not well understood. A survey by (We Are Social, 2018) stated the e-tailing user in Indonesia only made to $40 \%$ from the Indonesia population, smaller than other countries e.g. in United Kingdom where the user is $78 \%$ from its populations. This number suggest that there are obstacles that prevent consumers to adopt e-tailing in Indonesia. Different with social commerce platform that was not developed for online transaction purpose, e-tailing platform should be built to accommodate prospective consumers' needs to be accepted as new shopping channel. Reference (Davis, 1989; O'Cas $\&$ Fenech, 2003; Hong, Thong \& Tam, 2006; Noviarni, 2014) propose the technology acceptance model (TAM) i.e. perceived ease of use, perceived usefulness, and attitude towards using as a valid theoritical framework to understand consumers' adoption to technology. TAM mainly explain how users understand and apply a system information technology (Davis, 1989).

Driven by identified gap, this study aims to assess the role of technology acceptance model on etailing consumers' adoption in Indonesia. The Indonesian fashion industry was the logical context for this study as the fast growing of the industry in these past years was mainly supported by e-tailing. In 2017, "apparel" was the second most searched keyword in Google Indonesia and one of the fastest growing with 30\% historical growth (Moore, Akib \& Sugden, 2018). This trend in the consumers' behavior shall be followed by a serious move of fashion business in developing its online retail platform. Therefore, understanding technology acceptance model significance on e-tailing consumers' adoption is certainly important for Indonesian fashion retail industry.

\section{Literature Review}

\subsection{Technology Acceptance Model (TAM)}

TAM is one of many theories that used behavioral theory approach which frequently employed to review technology use. According to (Davis, Bagozzi \& Warshaw, 1989; Fatmawati, 2015; Handayani \& Mugi, 2016), the concept of technology acceptance model is a theory which offers a basis to understand the behavior of technology user in accepting and using offered technology. TAM is believed to be able to explain user acceptance for the technology based on perceived usefulness and perceived ease of use. Figure 2 shows technology acceptance model (TAM) developed by (Davis, 1989).

Reference (Davis, 1989) stated that perceived ease of use is a level where a person believes the use of certain technology decrease the weight of his effort to work on something, lead to frequent use. Several indicators for perceived ease of use are ease of learn, controllable, clear and understandable, flexible, easy to become skillful, and ease to use. Perceived usefulness is defined as a measure to the uses of a technology that is believed will bring benefits to people using it (Davis, 1989). Several indicators for perceived usefulness which are work more quickly, improve job performance, improve job perfromance, effectiveness, increase productivity, makes job easier and useful (Davis, 1989; 
Noviarni, 2014; Yahyapour, 2008). According to (Davis, 1989) attitude toward using in TAM is concepted as an attitude toward the use of technology which is either acceptance or rejection, as an impact of the technology uses in his or her work.

\subsection{Adoption Behavior}

Adoption process can be seen from a person who decide to make himself/herself as a regular user from a product/service (Noviarni, 2014). To measure e-tailing adoption, this study uses a question of "are you using e-tailing platform for buying a product" with double possible answers of "yes" or "no". This measurement can be accepted as it is taken from real behavior (O'Cas \& Fenech, 2003; Noviarni, 2014).

From the literatures reviewed, the hypothesis to be tested in this study as follows:

H1: Perceived ease of use (PEU) positively impact perceived usefulness (PU)

H2: Perceived usefulness (PU) positively impact attitude toward using (ATU)

H3: Perceived ease of use (PEU) positively impact attitude toward using (ATU)

H4: Attitude toward using (ATU) positively impact consumer adoption (CA)

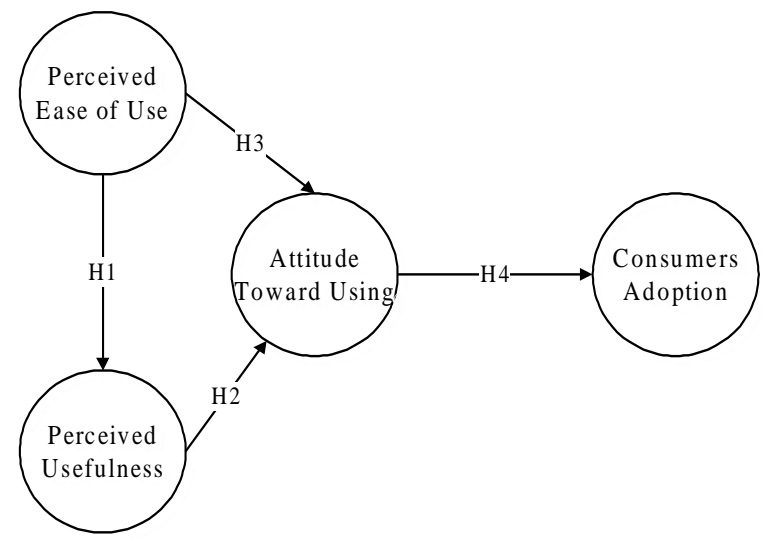

Image 1. Research Model

\section{Research Method}

\subsection{Data Analysis and Sample}

Technology Acceptance Model (TAM) was used in developing research model. According to (Davis, 1989; Fatmawati, 2015; Handayani \& Mugi, 2016), TAM is a theory which offers a basis to understand the behavior of technology user in accepting and using technology offered. In this research, the model divided to three constructs which are perceived usefulness, perceived ease of use, and attitude towards using.

This study used a quantitative approach because the purpose is to explain the correlation between variables through hypothetical tests. Data analysis techniques for this research is using structural equation modeling (SEM) by analysis of moment structures (AMOS). According to (Hair, Hult \& Ringle, 2014; Santoso, 2018), SEM is an evaluation for equation developed from econometric principal and combined with setting principal (analysis factor). This SEM is used to analyze the cause and effect relation between variables where every variable is bound (endogen) uniquely determined by a set of free (exogenous) variables (Riduwan \& Kuncoro, 2011). Studies with this method is used to explore the influence pattern between variables.

The model was estimated with 200 sample using maximum likelihood (ML) estimation. Data sample size used in this research is meeting the SEM assumption, which is in the recommended range of 100 - 200 data (Hair, Hult \& Ringle, 2014; Santoso, 2018; Latan, 2013). 


\subsection{Validity and Reliabity Test}

Validity test in this study was done using the Statistic Product and Service Solution (SPSS) because AMOS cannot count composite reliability automatically (Latan, 2013). Indicator is considered valid if the value $r_{\text {count }}>r_{\text {table }}$ with the level of significance of 0.05 or $5 \%$. All question items in this study meet the criteria, showing the value of coefficient correlation $>0,361$. Thus it can be concluded that the instrument used in this study was valid. A construct is considered reliable if the value of composite reliability or Cronbach's alpha more than 0,70 (Sugiyono, 2017). The value of Cronbach's alpha in this study was 0.778 for $\mathrm{X}$ variable and 0.881 for $\mathrm{Y}$ variable. With the mentioned values, the instrument used in this study is considered meeting the term of reliability.

\section{Result and Discussion}

\subsection{Path Analysis and Hypothesis Testing}

Path analysis was conducted in order to evaluate the relationship between the dependent variable of the technology acceptance to e-tailing adoption. The hypothesized relationship in the proposed model were simultaneously tested via path analysis, and the result is depicted in the table 1 and table 2 . The goodness of fit statistic form the path analysis showed that the model reasonably fits the data. The overall fit of the model appeared to be acceptable with $\chi 2=52.94$, $\mathrm{df}=1.54$, GFI $=0.97$, RMSEA $=0.05$, AGFI $=0.98, \mathrm{NFI}=0.96$, TLI $=1.25$, and $\mathrm{CFI}=0.91$.

Table 1 Model Fit Statistic

\begin{tabular}{|l|l|l|l|}
\hline Criterion Index & Cut Off Value & Result Value & Conclusion \\
\hline Chi-Square $(\chi 2)$ & Small value & 52.94 & \\
\hline df & $\leq 2.00$ & 1.54 & Good fit \\
\hline GFI & $>0.90$ & 0.97 & Good fit \\
\hline RMSEA & $<0.08$ & 0.05 & Good fit \\
\hline AGFI & $>0.90$ & 0.98 & Good fit \\
\hline NFI & $>0.90$ & 0.96 & Good fit \\
\hline TLI & $>0.90$ & 1.25 & Good fit \\
\hline CFI & $>0.90$ & 0.91 & Good fit \\
\hline
\end{tabular}

Note: $\mathrm{df}=$ degree of freedom; GFI = goodness of fit index; RMSEA = root mean square error of approximation; AGFI = adjusted goodness of fit index; NFI = normed fit index; TLI $=$ Tucker - Lewis index; $\mathrm{CFI}=$ comparative fit index

The hypothesis was tested through structural coefficients within the model. First hypothesis purpose to test the influence of perceived ease of use toward perceived usefulness was supported by the path analysis $(\mathrm{CR}=2.726, \mathrm{p}=<0.01)$. Thus, $\mathrm{H} 1$ is accepted. The expected impact of perceived usefulness $(\mathrm{CR}=2.335, \mathrm{p}=<0.05)$, as well as perceived ease of use $(\mathrm{CR}=1.764, \mathrm{p}=<0.05)$ toward attitude towards using were also supported, confirms that $\mathrm{H} 2$ and $\mathrm{H} 3$ are accepted. The result of path analysis indicate that adoption behavior was influenced by attitude toward using $(\mathrm{CR}=2.893, \mathrm{p}=<0.01)$. This notion thus confirming $\mathrm{H} 4$.

Table 2 Result of Path Analysisand Hypothesis Testing

\begin{tabular}{|c|c|c|c|}
\hline Path Analysis & Effect & CR & $\begin{array}{c}\text { Hypothesis } \\
\text { Testing }\end{array}$ \\
\hline $\begin{array}{c}\text { H1: PEU } \rightarrow \\
\text { PU }\end{array}$ & $\begin{array}{c}0.338^{*} \\
* *\end{array}$ & 2.726 & Supported \\
\hline $\begin{array}{c}\text { H2: PU } \rightarrow \\
\text { ATU }\end{array}$ & $\begin{array}{c}0.056^{*} \\
*\end{array}$ & 2.335 & Supported \\
\hline
\end{tabular}




\begin{tabular}{|c|c|c|c|}
\hline $\begin{array}{c}\text { H3: PEU } \rightarrow \\
\text { ATU }\end{array}$ & $\begin{array}{c}0.124^{*} \\
*\end{array}$ & 1.764 & Supported \\
\hline $\begin{array}{c}\text { H4: ATU } \rightarrow \\
\text { CA }\end{array}$ & $\begin{array}{c}0.495^{*} \\
* *\end{array}$ & 2.893 & Supported \\
\hline
\end{tabular}

Note: $\mathrm{CR}=$ composite reliability; $* * \mathrm{p}<0.05 ; * * * \mathrm{p}<0.01$

\subsection{Discussion}

The positive relation between perceived ease of use and perceived usefulness support past studies (O'Cas \& Fenech, 2003; Noviarni, 2014). It means that developing e-tailing platform's features that are easy to be operated by users, clear design, flexible system will lead to an increased perception of platform usefulness. This study proved that the usefulness rather influence attitude of the e-tailing platform user. Although the result comes different with the past study (Utomo \& Walujo, 2018), the context of e-tailing platform that covers the range of retail consumers' needs from product specification to delivery tracking logically needs to be perceived as practical and benefit the consumers' shopping process. The result of perceived ease of use that has a significant influence towards attitude towards using support past study (Utami \& Tulipa, 2006). This finding shows that e-tailing platform's performance in accommodating consumers' needs without much hassle will give a positive attitude of using the platform. In the end, this positive attitude will significantly lead to consumers e-tailing adoption.

Findings of this study suggests fashion company to improve the ease of operating their e-tailing platform, adding new features which fulfills what the customer wants, making the transaction process much faster, that can be done by streamlining the purchase step in the product purchasing and increase website's bandwidth capacity to widen the user coverage frequency. Further, the company needs to build a positive impression of consumers towards platform use. For example, by making the website interface more interesting, adding different contents every specific time, adding interaction feature in the website which collect responses such as complain or question. All efforts mentioned are specifically aiming for giving more value to consumers when using e-tailing platform.

\section{Conclusions}

This study confirms the importance of perceived ease of use in influencing perceived usefulness. Both of perceived ease of use and perceived usefulness, then, contribute in influencing attitude towards using. Lastly, positive attitude towards using has a significant influence to promote e-tailing consumer adoption. This finding contributes to a new understanding that to encourage consumers in using etailing platform, the company should pay attention to the ease of use and usefulness of their platform.

\section{Reference}

Das, K., Tamhane, T., Vatterott, B., Wibowo, P. \& Wintels, S. (2018). The digital archipelago: How Online commerce is driving Indonesia's economic development. Jakarta: McKinsey \& Company.

Davis, F. (1989). Perceived Usefulness, Perceived Ease of Use, and User Acceptance of Information Technology. MIS Quarterly, 13 (3), 319-340.

Davis, F. D., Bagozzi, R. P. \& Warshaw, P. R. (1989) User Acceptance of Computer Technology: a Comparison of Two Theoretical Models. Management Science, 35 (8), 982-1003.

Fatmawati, E. (2015). Technology Acceptance Model (TAM) untuk Menganalisis Penerimaan Terhadap Sistem Informasi Perpustakaan. J. Iqra', 9 (1), 310-315.

Hair, J. F., Hult, G. T. \& Ringle, C. M. (2014). a Primer on Partial Least Squares Structural Equation Modeling (PLS-SEM). California: SAGE Publication.

Handayani, W. P. P. \& Mugi, H. (2016) Aplikasi Technology Acceptance Model (TAM) pada Komputerisasi Kegiatan Pertanahan. Jurnal Economi, 12 (1), 142-147.

Hong, S. J., Thong, J. Y. L. \& Tam, K. Y. (2006). Understanding Continuer Information Technology Usage Behaviour: a Comparison of The Models in the Context of Mobile Internet. Decision Support System, 42, 1819-1834.

Indonesia Internet Service Provider Association. (2018, March 11). Hasil Survei Penetrasi dan Perilaku Pengguna Internet Indonesia 2017. Retrieved from https://apjii.or.id/content/read/39/342/ 
Latan, H. (2013). Model Persamaan Struktural Teori dan Implementasi AMOS 21.0. Bandung: Alfabeta.

Moore, B., Akib, K. \& Sugden, S. (2018) E-commerce in Indonesia: A guide for Australian Business. Australian Trade and Investment Commission (Austrade).

Nugroho, A. (2006). E-commerce Memahami Perdagangan Modern di Dunia Maya. Bandung: Informatika, Indonesia Internet Service Provider Association.

Noviarni, E. (2014). Analisis Adopsi Layanan Internet Bangking oleh Nasabah Perbankan di Pekanbaru (Technology Acceptance Model). Jurnal Al-Iqtishad, 10 (1), 27-39.

O'Cas, A, T. \& Fenech. (2003). Web Retailing Adoption: Exploring the Nature of Internet Users Web Retailing Behavior. Journal of Retailing and Cons. Serv, 10, 81-94.

Riduwan \& Kuncoro, E. A. (2011). Cara Menggunakan dan Memaknai Path Analysis (Analisis Jalur). Bandung: Alfabeta.

Santoso, S. (2018) Konsep Dasar dan Aplikasi SEM dengan AMOS 24. Jakarta: PT. Elex Media Komputindo.

Sugiyono. (2017). Metode Penelitian Kuantitatif, Kualitatif dan R\&D. Bandung: Alfabeta.

Utami, C. W. \& Tulipa, D. (2006). Technology Acceptance dan Consumer Decision Model Sebagai Dasar Pembangunan Model Niat Adopsi Teknologi Internet Dikalangan Pengguna Internet. Jurnal Widya Manajemen dan Akuntansi, 6 (1), 52-71.

Utomo, Y. \& Walujo. (2018). Penerapan Konstruk Technology Acceptance Model (TAM) pada Layanan Mobile Application di PDAM Surya Sembada Kota Surabaya. Jurnal Teknik WAKTU, $16,39-48$.

We Are Social. (2018, March 11). E-Commerce Revenues 2017. Retrieved from https://wearesocial.com/special-reports/digital-in-2017-global-overview

Yahyapour, N. (2008). Determining Factors Affecting Intention to Adopt Banking Recommender System, Case of Iran, Thesis, Lulea University Of Technology Division Of Industrial Marketing and E-commerce. Journal of Marketing and E-commerce, 9, 201-242.

*Email korespondensi:

afahlevideisti@gmail.com 